Scientific Paper

\title{
Contribution of soil in the annual effective dose due to radon in the air of some dwellings in the city of Karbala, Iraq
}

\author{
Abdalsattar Kareem HASHIMa, ${ }^{a}$, Laith Ahmed NAJAM ${ }^{b}$, Firas Mohammed Ali ALJOMAILYb \\ ${ }^{a}$ Department of Physics, College of Science, Kerbala University, Karbala, Iraq \\ ${ }^{b}$ Department of Physics, College of Science, Mosul University, Mosul, Iraq \\ *E-mail address: abdalsattarkareem@gmail.com,abdalsattar.kareem@uokerbala.edu.iq
}

\begin{abstract}
Introduction: The radon isotopes are not as significant as $\left({ }^{222} \mathrm{Rn}\right)$ due to the decay of the natural radionuclides $\left({ }^{235} \mathrm{U}\right)$, $\left({ }^{232} \mathrm{Th}\right)$ and $\left({ }^{238} \mathrm{U}\right)$ due to their short half-life, at most. $\left({ }^{222} \mathrm{Rn}\right)$ can be classified as among the most harmful radioactive elements in the world.

Material and method: In this analysis, the closed-can technique was used with solid-state nuclear track detectors (CR39). After forty days of closed dosimeter buried in the soil of the garden, and ninety days from the closed position in the air of some dwellings were collected dosimeter and stripped of nuclear detectors impact of closed groups. For 8 hours, CR-39 detectors were chemically etched by $(6.25 \mathrm{~N}) \mathrm{NaOH}$ solution at $70^{\circ} \mathrm{C}$ and then registered within an optical microscope.

Result: The levels of soil radon concentrations ranged from $28.44 \pm 0.58$ to $479.76 \pm 2.43 \mathrm{~Bq} / \mathrm{m}^{3}$ with a mean value of $220.33 \pm 1.64 \mathrm{~Bq} / \mathrm{m}^{3}$, while the concentration of radon in the air of certain dwellings varied from ( $1.95 \pm 0.27$ to $46.82 \pm 0.75$ ) $\mathrm{Bq} / \mathrm{m}^{3}$ with an average value of $21.51 \pm 0.54 \mathrm{~Bq} / \mathrm{m}^{3}$. In comparison, the annual effective dose attributed to radon in soil ranged from $0.71 \pm 0.09 \mathrm{mSv} / \mathrm{y}$ to $12.10 \pm 0.38 \mathrm{mSv} / \mathrm{y}$ with an average value of $5.55 \pm 0.261 \mathrm{mSv} / \mathrm{y}$, while the annual effective dose in air differed from $(0.04 \pm 0.02 \mathrm{mSv} / \mathrm{y})$ to $(1.18 \pm 0.12 \mathrm{mSv} / \mathrm{y})$ with an average value of $(0.60 \pm 0.09 \mathrm{mSv} / \mathrm{y})$. Conclusion: Neglecting the effects of other radon sources, the percentage share of the annual effective dose due to radon in soil measured in the air home, ranged from $0.005 \pm 0.001$ to $0.453 \pm 0.074$ with an average value of $0.130 \pm 0.040$. Weak correlation between concentrations of radon in households and soil air. But roughly speaking, one can say that in soil air every $1000 \mathrm{~Bq} / \mathrm{m}^{3}$ and $1000 \mathrm{mSv} / \mathrm{y}$ contributes around $130 \mathrm{~Bq} / \mathrm{m}^{3}$ and $130 \mathrm{mSv} / \mathrm{y}$ in indoor air.
\end{abstract}

Key words: radon concentration; (AED); SSNTD (CR-39); soil; air; dwelling.

\section{Introduction}

The radon isotopes are not as significant as $\left({ }^{222} \mathrm{Rn}\right)$ due to the decay of the natural radionuclides $\left({ }^{235} \mathrm{U}\right),\left({ }^{232} \mathrm{Th}\right)$ and $\left({ }^{238} \mathrm{U}\right)$ due to their short half-life, at most. $\left({ }^{222} \mathrm{Rn}\right)$ can be classified as among the most harmful radioactive elements in the world. Its character as a noble gas lets it spread through the atmosphere. ${ }^{1}$ The half-lives of ${ }^{219} \mathrm{Rn}$ (actinon, $3.96 \mathrm{~s}$ ) and ${ }^{220} \mathrm{Rn}$ (Thoron, $55.6 \mathrm{~s}$ ) are short, and they have a low abundance relative to ${ }^{222} \mathrm{Rn}$ (Radon, $3.82 \mathrm{~d}$ ). Because of these properties and dosimetric considerations; the alpha dose delivered to the trachea bronchial tree from ${ }^{220} \mathrm{Rn}$ is one-third that from ${ }^{222} \mathrm{Rn}$ per unit exposure of radon ${ }^{222} \mathrm{Rn}$, which is generally of major interest. Special situations, either occupational or environmental, could pose unusual circumstances where measurement of Actinon $\left({ }^{219} \mathrm{Rn}\right)$ or Thoron $\left({ }^{220} \mathrm{Rn}\right)$ would be the primary concern but so far these situations have been rare. ${ }^{2}$ Normal radioactivity is the population's main reservoir of ionizing radiation. It is found in varying concentrations both in humans and in the surrounding ecosystem, the earth is the main source of constant exposure to human radiation regardless of its normal nature. This acts as a way of movement for the introduction of radionuclides into the environment; hence, the soil is the main source of radiological pollution. ${ }^{3}$ When present in ambient air, radon and its daughter progeny attached to aerosols constitute a significant radioactive threat to human lungs. Radon progeny accumulates in the lungs during respiration and irradiates the tissue thereby destroying the cells and can cause lung cancer. ${ }^{4}$ This study aims to determine how much soil contributes to the annual effective dose due to radon in the air of some of Karbala's dwellings after neglecting all other sources. We can determine the amount of contribution after the measurement of the concentration of radon in the soil and air dwellings of the study area and find a ratio of contribution between the two.

\section{Environmental framework}

Karbala is called the capital of the governorate of Karbala, and as part of the alluvial plain it is the districts of the Middle Euphrates and the Husayniyah River flows through its lands. As

(C) 2021 Abdalsattar Kareem Hashim, Laith Ahmed Najam, Firas Mohammed Ali Aljomaily. This is an open access article licensed under the Creative Commons Attribution-NonCommercial-NoDerivs License (http://creativecommons.org/licenses/by-nc-nd/4.0/). 
in Figure 1. From a strategic point of view, it is bordered to the north by the city of Baghdad, at a distance of $105 \mathrm{~km}$, and to the northwest by the city of Anbar, at a distance of $112 \mathrm{~km}$; and the governorate of Najaf borders it to the south-west, at a distance of $45 \mathrm{~km}$, along with the governorate of Babylon, bordering it to the south-east, and the free zone bordering it to the north, Though sand increases to the south of the town of Karbala and its sand increases to the west, where Lake Al-Razzaza is situated, Karbala covers a region of up to $2793 \mathrm{~km}^{2}$, with latitude position $\left(32.34^{\circ}-32.37^{\circ} \mathrm{N}\right)$ and longitude $\left(58.43^{\circ}-60.44^{\circ} \mathrm{E}\right) .^{5}$ The soil was of sandy type: it contains small particles of rocks and minerals, and usually, the composition and structure of that soil are composed of sand consisting of rocks broken down by erosion factors, as it contains either a high or low percentage of organic matter and includes sand formation to more than $35 \%$ and less than $15 \%$ of clay and silt as it has a high rough texture and it should be noted that the percentage of sand, clay and silt is determined after disposal of organic matter in the soil.

\section{Materials and Methods}

In the current analysis, 55 houses were chosen in the district of Karbala, where one detector was randomly positioned in the house air and the other was buried in the garden of the house, which is 5-10 meters from the house. The houses that were selected for the study were built from bricks, cement, plaster, and parts of the houses were covered with ceramics and kashi, with a building area ranging from $50 \mathrm{~m}^{2}$ to $150 \mathrm{~m}^{2}$, and were built in different times, including the old and the modern. The integrated passive radon dosimeters of super grade standard SSNTDs CR-39 have been used, the methodology is based on the closed can (Figure 2). Such dosimeters are made of plastic containers with a diameter of $6.8 \mathrm{~cm}$ and a depth of $4.6 \mathrm{~cm}$. A triangular opening with a diameter of $0.75 \mathrm{~cm}$ was placed at the center of the cover. The gap was filled with a $1.3 \mathrm{~cm} \times 5 \mathrm{~cm}$ sponge piece and $0.5 \mathrm{~cm}$ long, pushed against the inner wall of the seal. Within the cup was placed a small piece of CR-39 with a region of roughly $2 \mathrm{~cm}^{2}$ and tied to its base. This configuration was sufficient to ensure thoron $\left({ }^{220} \mathrm{Rn} ; \mathrm{T} 1 / 2=55.6 \mathrm{~s}\right)$ did not penetrate the detector. On average, about 55dosimeters were typically spread within the dwellings of the chosen locations in each survey, as in Table 1. In each home, one dosimeter was placed in the room at a height of around $2 \mathrm{~m}$ above the floor, and radon was collected in the subsoil by putting the dosimeters upside-down at a depth of $50 \mathrm{~cm}$ in the earth at the bottom of the trap. Usually, the dosimeters were exposed inside the houses for three months to test radon in the dirt. Though the dosimeters were left to measure the radon gas in the soil for up to 40 days. In a beaker in a water bath equipped with an electrical heater and temperature $(70 \pm 0.1)$, the collected dosimeters were then chemically graved using a $\mathrm{NaOH}$ solution and an 8-hour concentration of (6.25)M topic. An optical microscope was used to count the number of tracks per $\mathrm{cm}^{2}$ recorded for each detector a magnification of $100 \times$ up to $400 \times$.

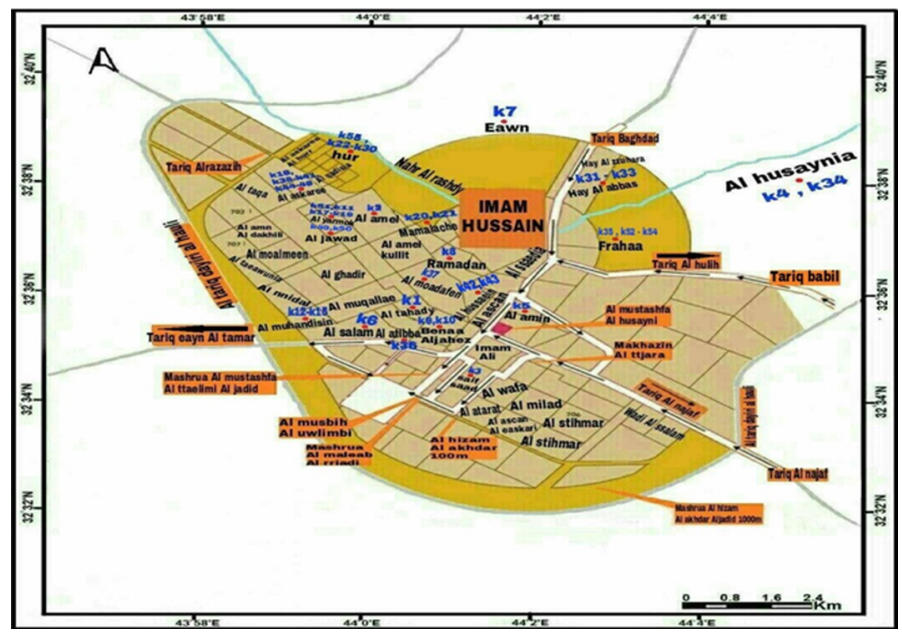

Figure 1. Map of location samples in Karbala city.

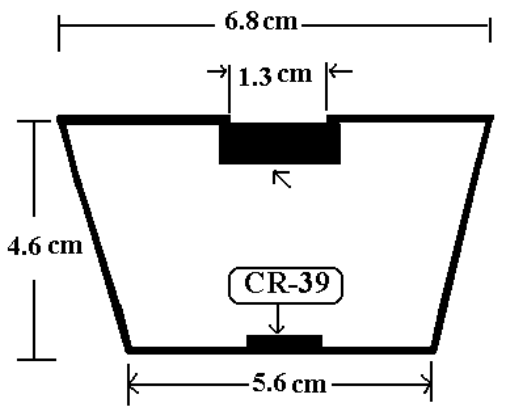

Figure 2. Passive-cumulative dosimeter radon

Table 1. Samples code and locations that have been selected in Karbala city

\begin{tabular}{|c|c|c|c|c|c|c|c|c|c|}
\hline Sample code & Location & Sample code & Location & Sample code & Location & Sample code & Location & Sample code & Location \\
\hline $\mathrm{K} 1$ & Tahady & K12 & \multirow{3}{*}{$\mathrm{Al}$ muhandisin } & K24 & \multirow{7}{*}{$\mathrm{Al}$ hur } & K35 & Frehaa & K46 & \multirow{3}{*}{ Askaree } \\
\hline $\mathrm{K} 2$ & Amel & K13 & & $\mathrm{K} 25$ & & K36 & Al atibba & K47 & \\
\hline K3 & Saif Saad & K14 & & K26 & & K37 & Al moadafeen & $\mathrm{K} 48$ & \\
\hline K4 & Hosainia & K16 & Askaree & K27 & & K38 & \multirow{4}{*}{ Askaree } & K49 & \multirow{2}{*}{ Al jawad } \\
\hline K5 & Alamin & K17 & \multirow{3}{*}{ Yarmouk } & $\mathrm{K} 28$ & & K39 & & K50 & \\
\hline K6 & Salam & K18 & & K29 & & $\mathrm{K} 40$ & & K51 & Yarmouk \\
\hline K7 & Eawn & K19 & & $\mathrm{K} 30$ & & $\mathrm{~K} 41$ & & K52 & \\
\hline K8 & Ramadan & K20 & \multirow{2}{*}{ Mamalachy } & K31 & \multirow{3}{*}{ Al abbas } & K42 & \multirow{2}{*}{ Al hussein } & K53 & Frehaa \\
\hline K9 & \multirow{2}{*}{ Benaa al jahez } & $\mathrm{K} 21$ & & K32 & & $\mathrm{K} 43$ & & K54 & \\
\hline $\mathrm{K} 10$ & & $\mathrm{~K} 22$ & \multirow{2}{*}{$\mathrm{Al}$ hur } & K33 & & K44 & \multirow{2}{*}{ Askaree } & K55 & Al hur \\
\hline K11 & Yarmouk & K23 & & K34 & Hosainia & K45 & & & \\
\hline
\end{tabular}


In order to measure the $\operatorname{radon}(\mathrm{C})$ concentrations in the soil and air of the buildings, the trace surface density on the detectors used was measured in (line $/ \mathrm{cm}^{2}$ ) and using the equation below: ${ }^{\mathbf{6}, 7}$

$C=\frac{\rho}{k t}$

Eq. 1

Where $\mathrm{t}$ is the exposure period (day) and $\mathrm{k}$ is the CR-39 nuclear track detector adjustment factor equivalent to $0.223\left[\left(\mathrm{track} / \mathrm{cm}^{2}\right)\right.$ per $\left(\mathrm{Bq}\right.$ day $\left.\left./ \mathrm{m}^{3}\right)\right]^{8}$ The calibration factor $(\mathrm{k}$ value was determined by the calibration process which used standard radon source (Radium ${ }^{226} \mathrm{Ra}$ ) and used the equation

$$
k=\frac{\rho_{0}}{C_{0} t_{0}}
$$

Eq. 2

where, $C_{0}$ is the standard radon concentration $\left(\mathrm{Bq} / \mathrm{m}^{3}\right), \rho_{0}$ is the number of track density (track/ $\mathrm{cm}^{2}$ ), and $t_{0}$ is the exposure time day for the calibration process. The calibration experiment was performed at the nuclear laboratory, department of physics, college of sciences, Kerbala University. Five detectors were exposed to the standard radon concentration; the average value of calibration factor and its standard deviation was 0.223 track $/ \mathrm{cm}^{2}$ per $\left(\right.$ day $\left.\mathrm{Bq} / \mathrm{m}^{3}\right){ }^{\mathbf{8}}$

In terms of (mSv/y) units, the annual effective dosage (AED) was obtained using the relationship: $:^{9,10}$

$$
A E D(m S v / y)=C \times F \times H \times T \times D
$$

where $\mathrm{F}$ is the equilibrium parameter equivalent to $(0.4),(\mathrm{H})$ the occupancy parameter equivalent to $(0.8),(\mathrm{T})$ the hour in a year, $(\mathrm{T}=8760 \mathrm{~h} / \mathrm{y})$, and (D) the transition dosage factor equivalent to $\left[9 \times 10^{-6}(\mathrm{mSv}) /\left(\mathrm{Bq} \cdot \mathrm{h} \cdot \mathrm{m}^{-3}\right)\right]$.

\section{Results}

To achieve the aims of this research, we examined the concentration of radon gas in the air of some sample region dwellings by administering passive closed dosimeters. As we analyzed the concentration of radon in the soil at a depth $(50 \mathrm{~cm})$ in the research region to find a connection between the radon concentration in the soil and the dwellings in the environment. Furthermore, assessing the amount of soil adds to the successful annual exposure attributable to radon in the environment of some of Karbala's dwellings by neglecting all other outlets. Table 2 indicates closed dosimeter radon concentrations in soil and radon concentrations in (55) homes in Karbala District, it can be noted that the maximum average soil (Cs) radon concentration was found in K45 and K46 $\left(479.76 \pm 2.43 \mathrm{~Bq} / \mathrm{m}^{3}\right)$, Whereas the lowest average concentration of radon in soil $\left(28.44 \pm 0.58 \mathrm{~Bq} / \mathrm{m}^{3}\right)$ was identified in $\mathrm{K} 1$ and $\mathrm{K} 15$ with a mean value of $220.33 \pm 1.64 \mathrm{~Bq} / \mathrm{m}^{3}$. It can also be observed from Table 2 that the radon concentrations in air dwellings $(\mathrm{Ca})$ vary from $\left(1.95 \pm 0.27 \mathrm{~Bq} / \mathrm{m}^{3}\right)(\mathrm{K} 16)$ to $\left(46.82 \pm 0.75 \mathrm{~Bq} / \mathrm{m}^{3}\right)(\mathrm{K} 32$ and $\mathrm{K} 53)$, with an average value of $\left(21.51 \pm 0.54 \mathrm{~Bq} / \mathrm{m}^{3}\right)$. Furthermore, the annual effective soil radon dose (AEDs) ranged from $0.71 \pm 0.09 \mathrm{mSv} / \mathrm{y}$ in $\mathrm{K} 1$ and $\mathrm{K} 15$ to $12.10 \pm 0.38$ $\mathrm{mSv} / \mathrm{y}$ in $\mathrm{K} 45$ and $\mathrm{K} 46$ with an average value of $5.55 \pm 0.261$ $\mathrm{mSv} / \mathrm{y}$, although the annual effective dose ranges between $(0.04 \pm 0.02 \mathrm{mSv} / \mathrm{y})(\mathrm{K} 16)$ and $(1.18 \pm 0.12 \mathrm{mSv} / \mathrm{y})(\mathrm{K} 32$ and $\mathrm{K} 53)$ with an overall value of $(0.60 \pm 0.09 \mathrm{mSv} / \mathrm{y})$ in air dwellings (AED a). Figure 3 shows the weak correlation $\left(\mathrm{R}^{2}=0.0569\right)$ between radon concentrations in household air and soil.

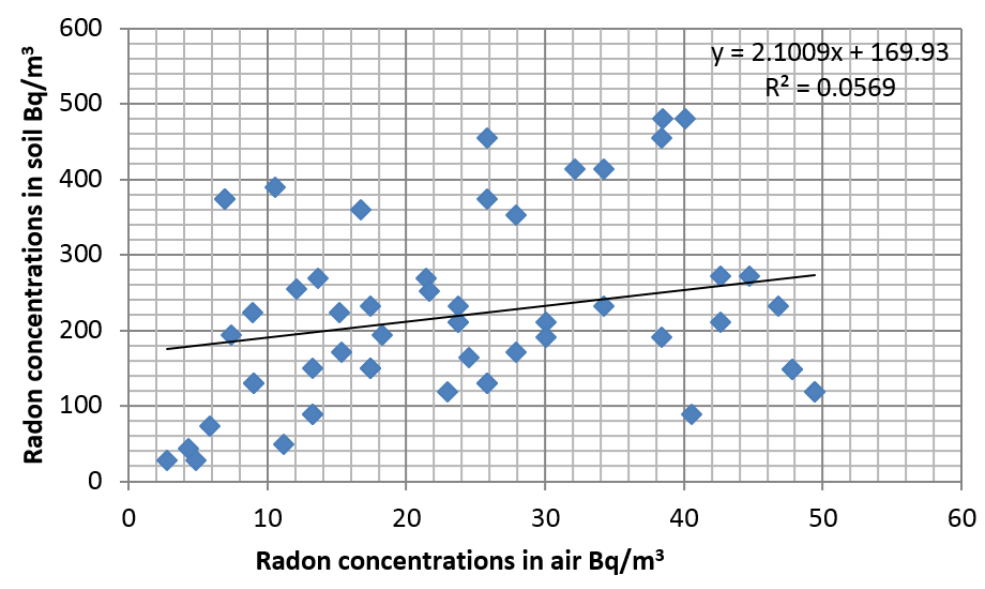

Figure 3. Correlation between radon concentration in air and soil 
Table 2. The track density in air $\left(\rho_{a}\right)$ and soil $\left(\rho_{s}\right)$, the radon concentration in air $\left(C_{a}\right)$ and soil $\left(C_{s}\right)$, annual effective dose in air $\left(A E D_{a}\right)$ and soil $\left(A E D_{s}\right)$ for (55) houses in Karbala city.

\begin{tabular}{|c|c|c|c|c|c|c|}
\hline \multirow{3}{*}{ Codes } & \multicolumn{3}{|c|}{ Air } & \multicolumn{3}{|c|}{ Soil } \\
\hline & $\rho_{a}$ & $C_{a}$ & $A E D_{a}$ & $\rho_{s}$ & $C_{s}$ & $A E D_{s}$ \\
\hline & Track/cm ${ }^{2}$ & $\mathrm{~Bq} / \mathrm{m}^{3}$ & $\mathrm{mSv} / \mathrm{y}$ & Track/cm ${ }^{2}$ & $\mathrm{~Bq} / \mathrm{m}^{3}$ & $\mathrm{mSv} / \mathrm{y}$ \\
\hline K1 & $55.00 \pm 0.82$ & $2.74 \pm 0.18$ & $0.06 \pm 0.02$ & $133.18 \pm 1.28$ & $28.44 \pm 0.58$ & $0.71 \pm 0.09$ \\
\hline $\mathrm{K} 2$ & $86.21 \pm 0.92$ & $4.29 \pm 0.23$ & $0.10 \pm 0.03$ & $203.63 \pm 1.58$ & $43.48 \pm 0.72$ & $1.09 \pm 0.11$ \\
\hline K3 & $117.42 \pm 1.08$ & $5.85 \pm 0.26$ & $0.14 \pm 0.04$ & $344.53 \pm 2.06$ & $73.57 \pm 0.94$ & $1.85 \pm 0.15$ \\
\hline K4 & $48.63 \pm 0.69$ & $2.34 \pm 0.30$ & $0.05 \pm 0.04$ & $908.15 \pm 3.34$ & $193.92 \pm 1.54$ & $4.89 \pm 0.24$ \\
\hline K5 & $560.56 \pm 2.36$ & $27.93 \pm 0.57$ & $0.70 \pm 0.09$ & $798.89 \pm 3.13$ & $170.59 \pm 1.44$ & $4.30 \pm 0.23$ \\
\hline K6 & $602.69 \pm 2.45$ & $30.02 \pm 0.60$ & $0.75 \pm 0.09$ & $989.09 \pm 3.49$ & $211.21 \pm 1.61$ & $5.32 \pm 0.25$ \\
\hline K7 & $644.82 \pm 2.53$ & $32.12 \pm 0.62$ & $0.81 \pm 0.10$ & $1940.11 \pm 4.89$ & $414.28 \pm 2.26$ & $10.45 \pm 0.35$ \\
\hline K8 & $560.56 \pm 2.36$ & $27.93 \pm 0.57$ & $0.70 \pm 0.09$ & $1654.80 \pm 4.51$ & $353.36 \pm 2.08$ & $8.91 \pm 0.33$ \\
\hline K9 & $179.84 \pm 1.33$ & $8.96 \pm 0.31$ & $0.22 \pm 0.05$ & $1049.05 \pm 3.59$ & $224.01 \pm 1.66$ & $5.65 \pm 0.26$ \\
\hline K10 & $211.05 \pm 1.45$ & $10.51 \pm 0.35$ & $0.26 \pm 0.05$ & $1824.01 \pm 4.74$ & $389.49 \pm 2.19$ & $9.82 \pm 0.34$ \\
\hline K11 & $242.26 \pm 1.72$ & $12.07 \pm 0.38$ & $0.30 \pm 0.06$ & $1189.95 \pm 3.83$ & $254.10 \pm 1.77$ & $6.41 \pm 0.27$ \\
\hline $\mathrm{K} 12$ & $273.47 \pm 1.83$ & $13.62 \pm 0.40$ & $0.34 \pm 0.06$ & $1260.40 \pm 3.94$ & $269.14 \pm 1.82$ & $6.79 \pm 0.28$ \\
\hline K13 & $60.09 \pm 0.68$ & $2.99 \pm 0.76$ & $0.07 \pm 0.02$ & $696.79 \pm 2.93$ & $148.79 \pm 1.35$ & $3.75 \pm 0.21$ \\
\hline K14 & $91.30 \pm 1.05$ & $4.54 \pm 0.77$ & $0.11 \pm 0.03$ & $555.89 \pm 2.61$ & $118.70 \pm 1.20$ & $2.99 \pm 0.19$ \\
\hline K15 & $97.13 \pm 1.09$ & $4.84 \pm 0.24$ & $0.12 \pm 0.03$ & $133.18 \pm 1.28$ & $28.44 \pm 0.58$ & $0.71 \pm 0.09$ \\
\hline K16 & $39.26 \pm 0.69$ & $1.95 \pm 0.27$ & $0.04 \pm 0.02$ & $1749.91 \pm 4.70$ & $373.67 \pm 2.14$ & $9.42 \pm 0.34$ \\
\hline K17 & $81.39 \pm 1.00$ & $4.05 \pm 0.33$ & $0.10 \pm 0.03$ & $608.69 \pm 2.73$ & $129.97 \pm 1.26$ & $3.27 \pm 0.20$ \\
\hline K18 & $518.43 \pm 2.52$ & $25.83 \pm 0.55$ & $0.65 \pm 0.08$ & $2130.31 \pm 5.12$ & $454.90 \pm 2.36$ & $11.47 \pm 0.37$ \\
\hline K19 & $65.65 \pm 0.89$ & $3.27 \pm 0.40$ & $0.08 \pm 0.03$ & $418.48 \pm 2.27$ & $89.36 \pm 1.04$ & $2.25 \pm 0.16$ \\
\hline $\mathrm{K} 20$ & $686.95 \pm 2.91$ & $34.22 \pm 0.64$ & $0.86 \pm 0.10$ & $1940.11 \pm 4.89$ & $414.28 \pm 2.26$ & $10.45 \pm 0.35$ \\
\hline $\mathrm{K} 21$ & $349.91 \pm 2.07$ & $17.43 \pm 0.45$ & $0.44 \pm 0.07$ & $703.79 \pm 2.94$ & $150.28 \pm 1.36$ & $3.79 \pm 0.21$ \\
\hline $\mathrm{K} 22$ & $476.30 \pm 2.42$ & $23.73 \pm 0.53$ & $0.59 \pm 0.08$ & $1084.19 \pm 3.65$ & $231.51 \pm 1.68$ & $5.84 \pm 0.26$ \\
\hline K23 & $686.95 \pm 2.91$ & $34.22 \pm 0.64$ & $0.86 \pm 0.10$ & $1084.19 \pm 3.65$ & $231.51 \pm 1.68$ & $5.84 \pm 0.26$ \\
\hline K24 & $855.47 \pm 3.24$ & $42.62 \pm 0.72$ & $1.07 \pm 0.11$ & $1274.40 \pm 3.96$ & $272.13 \pm 1.83$ & $6.86 \pm 0.29$ \\
\hline $\mathrm{K} 25$ & $771.21 \pm 3.08$ & $38.42 \pm 0.68$ & $0.96 \pm 0.10$ & $2130.31 \pm 5.12$ & $454.90 \pm 2.36$ & $11.47 \pm 0.37$ \\
\hline K26 & $813.34 \pm 3.16$ & $40.52 \pm 0.70$ & $1.02 \pm 0.11$ & $418.48 \pm 2.27$ & $89.36 \pm 1.04$ & $2.25 \pm 0.16$ \\
\hline K27 & $855.47 \pm 3.24$ & $42.62 \pm 0.72$ & $1.07 \pm 0.11$ & $989.09 \pm 3.49$ & $211.21 \pm 1.61$ & $5.32 \pm 0.25$ \\
\hline K28 & $897.60 \pm 3.32$ & $44.72 \pm 0.73$ & $1.12 \pm 0.11$ & $1274.40 \pm 35.69$ & $272.13 \pm 1.83$ & $6.86 \pm 0.29$ \\
\hline K29 & $304.68 \pm 1.93$ & $15.18 \pm 0.43$ & $0.38 \pm 0.06$ & $1049.05 \pm 3.59$ & $224.01 \pm 1.66$ & $5.65 \pm 0.26$ \\
\hline K30 & $335.89 \pm 2.03$ & $16.73 \pm 0.44$ & $0.42 \pm 0.07$ & $1683.11 \pm 4.55$ & $359.41 \pm 2.10$ & $9.06 \pm 0.33$ \\
\hline K31 & $367.10 \pm 2.12$ & $18.29 \pm 0.47$ & $0.46 \pm 0.07$ & $908.15 \pm 3.34$ & $193.92 \pm 1.54$ & $4.89 \pm 0.24$ \\
\hline $\mathrm{K} 32$ & $939.73 \pm 3.40$ & $46.82 \pm 0.75$ & $1.18 \pm 0.12$ & $1084.19 \pm 3.65$ & $231.51 \pm 1.68$ & $5.84 \pm 0.26$ \\
\hline K33 & $602.69 \pm 2.72$ & $30.02 \pm 0.60$ & $0.75 \pm 0.09$ & $893.99 \pm 3.32$ & $190.90 \pm 1.53$ & $4.81 \pm 0.24$ \\
\hline K34 & $518.43 \pm 2.52$ & $25.83 \pm 0.55$ & $0.65 \pm 0.08$ & $1749.91 \pm 4.64$ & $373.67 \pm 2.14$ & $9.42 \pm 0.34$ \\
\hline $\mathrm{K} 35$ & $139.26 \pm 1.30$ & $6.93 \pm 0.27$ & $0.17 \pm 0.04$ & $1749.91 \pm 4.64$ & $373.67 \pm 2.14$ & $9.42 \pm 0.34$ \\
\hline K36 & $181.39 \pm 1.49$ & $9.03 \pm 0.33$ & $0.22 \pm 0.05$ & $608.69 \pm 2.73$ & $129.97 \pm 1.26$ & $3.27 \pm 0.20$ \\
\hline K37 & $223.52 \pm 1.65$ & $11.13 \pm 0.36$ & $0.28 \pm 0.05$ & $228.28 \pm 1.67$ & $48.74 \pm 0.76$ & $1.23 \pm 0.12$ \\
\hline K38 & $265.65 \pm 1.80$ & $13.23 \pm 0.40$ & $0.33 \pm 0.06$ & $418.48 \pm 2.27$ & $89.36 \pm 1.04$ & $2.25 \pm 0.16$ \\
\hline K39 & $307.78 \pm 1.94$ & $15.33 \pm 0.43$ & $0.38 \pm 0.06$ & $798.89 \pm 3.13$ & $170.59 \pm 1.44$ & $4.30 \pm 0.23$ \\
\hline K40 & $349.91 \pm 2.07$ & $17.43 \pm 0.45$ & $0.44 \pm 0.07$ & $703.79 \pm 2.94$ & $150.28 \pm 1.36$ & $3.79 \pm 0.21$ \\
\hline K41 & $349.91 \pm 2.07$ & $17.43 \pm 0.45$ & $0.44 \pm 0.07$ & $1084.19 \pm 3.65$ & $231.51 \pm 1.68$ & $5.84 \pm 0.26$ \\
\hline K42 & $429.52 \pm 2.30$ & $21.40 \pm 0.50$ & $0.54 \pm 0.08$ & $1260.40 \pm 3.94$ & $269.14 \pm 1.82$ & $6.79 \pm 0.28$ \\
\hline K43 & $460.73 \pm 2.38$ & $22.95 \pm 0.52$ & $0.57 \pm 0.08$ & $555.89 \pm 2.61$ & $118.70 \pm 1.20$ & $2.99 \pm 0.19$ \\
\hline K44 & $491.94 \pm 2.46$ & $24.51 \pm 0.54$ & $0.61 \pm 0.09$ & $767.24 \pm 3.07$ & $163.83 \pm 1.41$ & $4.13 \pm 0.22$ \\
\hline $\mathrm{K} 45$ & $772.83 \pm 3.08$ & $38.50 \pm 0.68$ & $0.97 \pm 0.10$ & $2246.72 \pm 5.26$ & $479.76 \pm 2.43$ & $12.10 \pm 0.38$ \\
\hline K46 & $804.04 \pm 3.15$ & $40.06 \pm 0.70$ & $1.01 \pm 0.11$ & $2246.72 \pm 5.26$ & $479.76 \pm 2.43$ & $12.10 \pm 0.38$ \\
\hline K47 & $434.17 \pm 2.31$ & $21.63 \pm 0.50$ & $0.54 \pm 0.08$ & $1179.30 \pm 3.81$ & $251.82 \pm 1.76$ & $6.35 \pm 0.27$ \\
\hline K48 & $476.30 \pm 2.42$ & $23.73 \pm 0.53$ & $0.59 \pm 0.08$ & $989.09 \pm 3.49$ & $211.21 \pm 1.61$ & $5.32 \pm 0.25$ \\
\hline K49 & $518.43 \pm 2.52$ & $25.83 \pm 0.56$ & $0.65 \pm 0.08$ & $608.69 \pm 2.73$ & $129.97 \pm 1.26$ & $3.27 \pm 2.00$ \\
\hline K50 & $265.65 \pm 1.80$ & $13.23 \pm 0.40$ & $0.33 \pm 0.05$ & $703.79 \pm 2.94$ & $150.28 \pm 1.36$ & $3.79 \pm 0.21$ \\
\hline K51 & $476.30 \pm 2.42$ & $23.73 \pm 0.54$ & $0.59 \pm 0.08$ & $989.09 \pm 3.49$ & $211.21 \pm 1.61$ & $5.32 \pm 0.25$ \\
\hline K52 & $518.43 \pm 2.52$ & $25.83 \pm 0.56$ & $0.65 \pm 0.08$ & $608.69 \pm 2.73$ & $129.97 \pm 1.26$ & $3.27 \pm 2.00$ \\
\hline K53 & $939.73 \pm 3.40$ & $46.82 \pm 0.75$ & $1.18 \pm 0.12$ & $960.09 \pm 3.44$ & $148.79 \pm 1.35$ & $3.75 \pm 0.21$ \\
\hline K54 & $555.89 \pm 2.61$ & $27.69 \pm 0.77$ & $0.69 \pm 0.09$ & $991.30 \pm 3.49$ & $118.70 \pm 1.20$ & $2.99 \pm 0.19$ \\
\hline K55 & $771.21 \pm 3.08$ & $38.42 \pm 0.68$ & $0.96 \pm 010$ & $893.99 \pm 3.32$ & $190.90 \pm 1.53$ & $4.81 \pm 0.22$ \\
\hline Mean & $427.04 \pm 2.29$ & $21.51 \pm 0.54$ & $0.60 \pm 0.09$ & $1044.54 \pm 3.59$ & $220.33 \pm 1.64$ & $5.55 \pm 0.261$ \\
\hline Max. & $939.73 \pm 3.40$ & $46.82 \pm 0.75$ & $1.18 \pm 0.12$ & $2246.72 \pm 5.26$ & $479.76 \pm 2.43$ & $12.10 \pm 0.38$ \\
\hline Min. & $39.26 \pm 0.69$ & $1.95 \pm 0.27$ & $0.04 \pm 0.02$ & $133.18 \pm 1.28$ & $28.44 \pm 0.58$ & $0.71 \pm 0.09$ \\
\hline
\end{tabular}




\section{Discussion}

The explanation for the variability of these recipes is attributed to the natural complexity of the land on which these houses were constructed, as well as the varying materials used in the design.

Table 3 and Figure 4 show that the amount of soil contribution to radon concentrations in the air of the homes of the study area.

Contribution to the soil at an annual effective dose due to radon in air dwellings $\left[\left(C_{a} / C_{s}\right]\right.$ or $\left[A E D_{a} / A E D_{s}\right]$ ranges from $0.005 \pm 0.001$ (K16) to $0.453 \pm 0.074$ (K26) with an average value of $(0.130 \pm 0.040)$, this means that every $1000 \mathrm{~Bq} / \mathrm{m}^{3}$ or 1000 $\mathrm{mSv} / \mathrm{y}$ in soil air contributes approximately $130 \mathrm{~Bq} / \mathrm{m}^{3}$ or 130 $\mathrm{mSv} / \mathrm{y}$ indoor air for both concentrations of radon and the annual effective radon gas dose, respectively. This means that the ratio between the rate of radon concentrations in residential air and the rate of radon concentrations in the soil as well as between the rate of the radon dose in the air and the rate of the radon dose in the soil is the same amount and this amount is called the contribution of soil to the concentrations and doses of radon produced in the air while neglecting all factors that affect radon concentration and dose.

The average concentration of soil gas radon in the city of Karbala is lower than that of $6.71 \mathrm{kBq} / \mathrm{m}^{3}$ in Saudi Arabia ${ }^{11}$ and $5.74 \mathrm{kBq} / \mathrm{m}^{3}$ in Iraq ${ }^{12}, 4.35 \mathrm{kBq} / \mathrm{m}^{3}$ in Egypt ${ }^{13}, 2.63 \mathrm{kBq} / \mathrm{m}^{3}$ in Kassala-Sudan ${ }^{14}$ and $2.71 \mathrm{kBq} / \mathrm{m}^{3}$ in France ${ }^{15}$. In comparison, the radon concentration levels in this sample are lower than those reported in $8.20 \mathrm{kBq} / \mathrm{m}^{3}$ of Rabak city Sudan ${ }^{\mathbf{1 6}}, 40.1$ $\mathrm{kBq} / \mathrm{m}^{3}$ of Slovenia ${ }^{17}$ and $2.87 \mathrm{kBq} / \mathrm{m}^{3}$ of $\mathrm{Iraq}^{8}$.

Considering the great importance of radon as a result of the health effects on human life, many researchers in various countries around the world conduct research and studies to measure the concentrations effective dose of it in the air of houses of those countries in order to reduce the risks resulting from it and develop the necessary solutions to it through special programs. By comparing the findings of the current research with the findings of local and international studies, we noticed that the concentrations of radon in the air of dwellings of the city of Karbala were lower than the concentration of radon in the air of both Iraq's houses ${ }^{18}$, Egypt ${ }^{19}$, France $^{20}$, Iraq ${ }^{21-23}$, Jordan ${ }^{24,25}$, Kosovo $^{26}$, Iran ${ }^{27}$, Ghana ${ }^{28}$, Palestine ${ }^{29}$, India ${ }^{30}$, Mali $^{31}$, Romania $^{32}$, Spain $^{33}$, Turkey ${ }^{34}$, Sudan $^{35}$, Iraq $^{36}{ }^{36}$ Libya $^{37}$, USA $^{38}$, Greece $^{39}$, Saudi Arabia ${ }^{40}$ and Yemen ${ }^{41}$.

Table 3. Contribution of soil to radon concentrations $C_{a} / C_{s}$ or annual effective dose $A E D_{a} / A E D_{s}$ in the air for (55) houses in Karbala city.

\begin{tabular}{|c|c|c|c|}
\hline Codes & $\begin{array}{c}C_{a} / C_{s} \\
\text { or } \\
A E D_{a} / A E D_{s}\end{array}$ & Codes & $\begin{array}{c}C_{a} / C_{s} \\
\text { or } \\
A E D_{a} / A E D_{s}\end{array}$ \\
\hline $\mathrm{K} 1$ & $0.096 \pm 0.034$ & K30 & $0.047 \pm 0.024$ \\
\hline $\mathrm{K} 2$ & $0.099 \pm 0.034$ & K31 & $0.094 \pm 0.034$ \\
\hline K3 & $0.075 \pm 0.030$ & K32 & $0.202 \pm 0.049$ \\
\hline K4 & $0.012 \pm 0.001$ & K33 & $0.157 \pm 0.044$ \\
\hline K5 & $0.164 \pm 0.044$ & K34 & $0.069 \pm 0.029$ \\
\hline K6 & $0.142 \pm 0.041$ & K35 & $0.019 \pm 0.015$ \\
\hline K7 & $0.078 \pm 0.031$ & K36 & $0.070 \pm 0.029$ \\
\hline K8 & $0.079 \pm 0.031$ & K37 & $0.228 \pm 0.053$ \\
\hline K9 & $0.040 \pm 0.022$ & K38 & $0.148 \pm 0.042$ \\
\hline K10 & $0.027 \pm 0.018$ & K39 & $0.090 \pm 0.033$ \\
\hline K11 & $0.048 \pm 0.024$ & K40 & $0.116 \pm 0.037$ \\
\hline K12 & $0.051 \pm 0.025$ & K41 & $0.075 \pm 0.091$ \\
\hline K13 & $0.020 \pm 0.011$ & K42 & $0.080 \pm 0.031$ \\
\hline K14 & $0.038 \pm 0.021$ & K43 & $0.193 \pm 0.048$ \\
\hline K15 & $0.170 \pm 0.045$ & K44 & $0.150 \pm 0.043$ \\
\hline K16 & $0.005 \pm 0.001$ & K45 & $0.080 \pm 0.031$ \\
\hline K17 & $0.031 \pm 0.009$ & K46 & $0.084 \pm 0.032$ \\
\hline K18 & $0.057 \pm 0.026$ & K47 & $0.086 \pm 0.032$ \\
\hline K19 & $0.036 \pm 0.012$ & K48 & $0.112 \pm 0.037$ \\
\hline K20 & $0.083 \pm 0.032$ & K49 & $0.199 \pm 0.049$ \\
\hline K21 & $0.116 \pm 0.037$ & K50 & $0.088 \pm 0.032$ \\
\hline $\mathrm{K} 22$ & $0.103 \pm 0.035$ & K51 & $0.112 \pm 0.037$ \\
\hline K23 & $0.148 \pm 0.042$ & K52 & $0.199 \pm 0.049$ \\
\hline K24 & $0.157 \pm 0.044$ & K53 & $0.322 \pm 0.063$ \\
\hline $\mathrm{K} 25$ & $0.084 \pm 0.032$ & K54 & $0.416 \pm 0.071$ \\
\hline K26 & $0.453 \pm 0.074$ & K55 & $0.201 \pm 0.049$ \\
\hline $\mathrm{K} 27$ & $0.202 \pm 0.049$ & Mean & $0.130 \pm 0.040$ \\
\hline K28 & $0.164 \pm 0.044$ & Max. & $0.453 \pm 0.074$ \\
\hline $\mathrm{K} 29$ & $0.068 \pm 0.028$ & Min. & $0.005 \pm 0.001$ \\
\hline
\end{tabular}

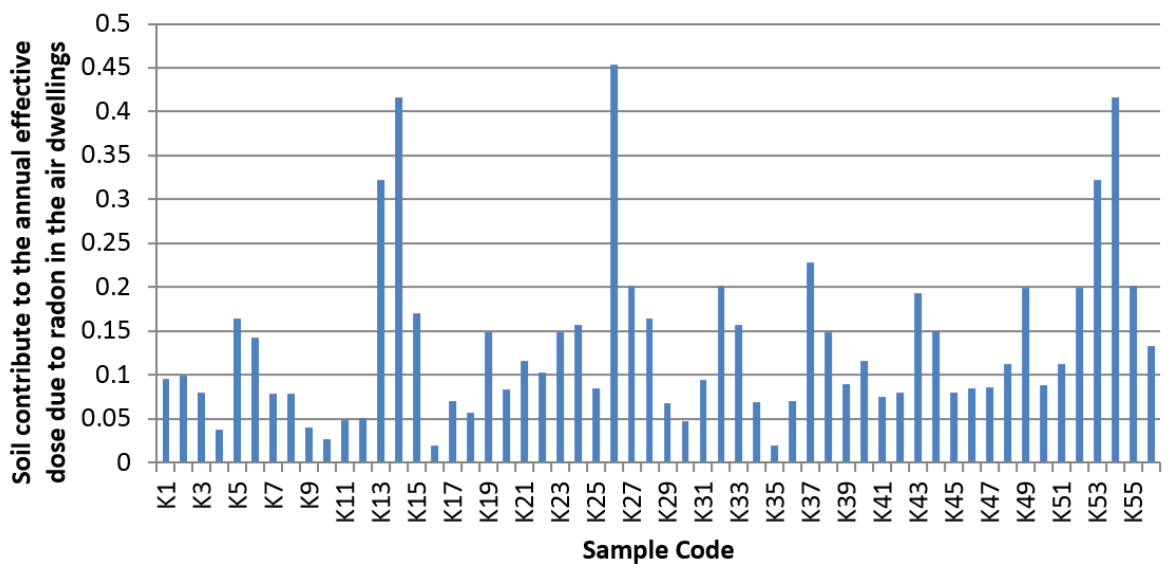

Figure 4. The percent of soil contribute to the annual effective dose due to radon in the air of fifty-five dwellings in the city of Karbala. 


\section{Conclusions}

Because of the results obtained in Karbala City's soil and air dwellings and comparing the results with other local and foreign research, we may conclude that such results may not present a major challenge to the lives of citizens residing in the field of analysis. This analysis found that soil radon concentrations range from $(28.44 \pm 0.58-479.76 \pm 2.43) \mathrm{Bq} / \mathrm{m}^{3}$ to the mean of (220.33 \pm 1.64$) \mathrm{Bq} / \mathrm{m}^{3}$, The values of radon concentrations in dwellings using dosimeters vary from $\left(1.95 \pm 0.27 \mathrm{~Bq} / \mathrm{m}^{3}\right)$ to $\left(46.82 \pm 0.75 \mathrm{~Bq} / \mathrm{m}^{3}\right)$ with an average value of $(21.51 \pm 0.54$ $\mathrm{Bq} / \mathrm{m}^{3}$ ), showing results within the permitted limits. In addition, we observed that the amounts of radon in Karbala dwellings and soil are below the standards recognized globally. Each 1000 $\mathrm{Bq} / \mathrm{m}^{3}$ of soil air contributes about $130 \mathrm{~Bq} / \mathrm{m}^{3}$ in dwellings' air. This means that the ratio between the rate of radon concentrations or annual effective dose in residential air and the rate of radon concentrations or annual effective dose in the soil, respectively.

\section{Acknowledgment}

The authors would like to thank the Head of the Physics Department at the Faculty of Science at Kerbala University for allowing us to use the graduate lab for this research.

\section{References}

1. Mansour HH, per Khdar S, Abdulla HY, et al. Measurement of indoor radon levels in Erbil capital by using solid state nuclear track detector. Radiation Measurement. 2005;40(2-6):544-547. https://doi.org/10.1016/j.radmeas.2005.06.033

2. NCRP (National Council on Radiation Protection and Measurements). Measurement of Radon and Daughters in Air. NCRP Report No. 97. Bethesda, (M.D.) U.S.A. 1988.

3. Verma D, Khan MS, Zubair M. Assessment of effective radium content and radon exhalation rates in soil samples. J Radioanal Nucl Chem. 2021;294(2). https://doi.org/10.1007/s10967-012-1694-1.

4. Mehra R, Singh S, Singh K. A Study of Uranium, Radium, Radon exhalation rate and indoor radon in the environs of some areas of the malwa region, Punjab. Indoor Built Environ. 2006;15(5):499-505. https://doi.org/10.1177/1420326X06069053

5. Sajet M. Spatial analysis of residential waste solid in the city of Karbala (a study in environment geography). Master Thesis. College of education for Humanities Geography, University of Karbala, 2015.

6. Hashim AK. A Study of Radon Concentration in the Soil and air of Some Villages in Irbid Governorate. M.Sc. Thesis, Yarmouk University, Jordan. 2003.

7. Asaad HI, Salih OH. Analysis of Radon Concentrations in Drinking Water in Erbil Governorate (Iraqi Kurdistan) and its Health Effects. Tikrit Journal of Pure Science. 2008;13:3.

8. Hashim AK, Mohammed EJ. Measurement of Radon Concentration and the Effective Dose Rate in the Soil of the City of Karbala. Iraq J Rad Nucl Appl. 2016;1(1):17-23. https://doi.org/10.18576/jrna/010103

9. Abumurad KM, Al-Omari RA. Indoor radon levels in Irbid and health risks from internal doses. Radiation Measurements. 2008;43:S389-S391. https://doi.org/10.1016/j.radmeas.2008.03.051

10. Hashim AK, Awad EI, Mezher HA. Measurement of annual effective dose for Radon in Kerbala University Campus, Freiha, Iraq. Iraqi Journal of Public Health. 2017;1(1):20-25.

11. Farid SM. Indoor radon in dwellings of Jeddah city, Saudi Arabia and its correlations with the radium and radon exhalation rates from soil. Indoor Built Environ. 2014;25(1):269-278. https://doi.org/10.1177/1420326X14536749

12. Shafik S, Mohammed AA. Measurement of Radon and Uranium Concentrations and Background Gamma Rays at the University of Baghdad - Jadiriyah Site. International Journal of Application or Innovation in Engineering \& Management (IJAIEM). 2013;2(5):455462.

13. Korany KA, Shata AE, Hassan SF, Nagdy MSE. Depth and Seasonal Variations for the Soil Radon-Gas Concentration Levels at Wadi Naseib Area, Southwestern Sinai, Egypt. J Phys Chem Biophys. 2013;3(4). https://doi.org/10.4172/2161-0398.1000123

14. Elzain AEA, Sam AK, Mukhtar OM, Abbasher MA. Measurements of Radon Gas Concentration in a Soil at Some Towns in Kassala State. Gezira Journal of Engineering \& Applied Sciences. 2009;4(1):15-42.

15. Baixeras C, Climent H, Font LI, Bacmeister GU, Albarracin D, Monnin M. Using Passive Detectors in Soil and Indoors in Tow Mediterranean Locations for Radon Concentration Measurements. Radiat Meas. 1997;28(1-6):713-716. https://doi.org/10.1016/S13504487(97)00169-8

16. Elzain AEA, Mohammed YS, Mohammed KS, Sumaia SM. Radium and Radon Exhalation Studies in Some Soil Samples from Singa and Rabak Towns, Sudan using CR-39. International Journal of Science and Research (IJSR). 2014;3(11):632- 637.

17. Brajnik D, Miklavžič U, Tomšič J. Map of natural radioactivity in Slovenia and its correlation to the emanation of radon. Radiation Protection Dosimetry. 1992;45:273-276. https://doi.org/10.1093/rpd/45.1-4.273 
18. Mansour HL, Tawfiq NF, Karim MS. Measurement of radon -222 concentrations in dwellings of Baghdad Governorate. Indian Journal of Applied Research. 2014;4(2). https://doi.org/10.15373/2249555X/FEB2014/160

19. Ghany HAA. Variability of radon levels in different rooms of Egyptian dwellings. Indoor and Built Environ. 2006;15(2):193-196. https://doi.org/10.1177/1420326X06063218

20. Baysson H, Billon S, Laurier D, Rogel A, Tirmarche M. Seasonal correction for estimation radon exposure in France dwellings. Radiat Prot Dosim. 2003;104(3):245-252. https://doi.org/10.1093/oxfordjournals.rpd.a006188

21. Hashim AK, Mezher HA. Radon Concentrations and Annual Effective Dose in Some Dwellings of Aun Region in Kerbala Governorate, Iraq. Journal of Kerbala University. 2016;14(1):103-111.

22. Tawfiq NF, Rasheed NO, Aziz AA. Measurement of Indoor Radon Concentration in Various Dwellings of Baghdad Iraq. International Journal of Physics. 2015;3(5):202-207. https://doi.org/10.12691/ijp-3-5-1

23. Abdalsattar Kareem Hashim and Elham Jasim Mohammed. Natural radioactivity due to radon in dwellings of Karbala city Iraq. Int $\mathbf{J}$ Adv Res. 2016;4(8):1164-1171. https://doi.org/10.21474/IJAR01/1318

24. Abu Murad KM, Al-Tamimi MH. Natural radioactivity due to radon in Soum region, Jordan. Radiation Measurements. 2005:39(1):7780. https://doi.org/10.1016/j.radmeas.2004.02.017

25. Ya'qouba MM, Al-Hamarneha IF, Al-Kofahib M. Indoor Radon Concentrations and Effective Dose Estimation in Dwellings of AsSalt Region in Jordan. Jordan Journal of Physics. 2009;2(3):189-196.

26. Bahtijari M, Vaupotic J, Gregoric A, Stegnar P, Kobal I. Exposure to Radon in Dwellings in The Sharri Community, Kosovo. Radiation Protection Dosimetry. 2008;130(2):244-248. https://doi.org/10.1093/rpd/ncm488

27. Hadad K, Hakimdavoud MR, Hashemi-Tilehnoee M. Indoor radon survey in Shiraz-Iran using developed passive measurement method. Iran J Radiat Res. 2011;9(3):175-182.

28. Nsiah-Akoto I, Fletcher JJ, Oppon OC, Andam AB. Indoor Radon Levels and the Associated Effective Dose Rate Determination at Dome in the Greater Accra Region of Ghana. Research Journal of Environmental and Earth Sciences. 2011;3(2):124-130.

29. Abu-Samreh MM, Thabayneh KM, Elayan MM. Assessment of indoor radon levels in some dwellings of Beit Fajjar city, Palestine. Hebron University Research Journal (A). 2012;6:47-60.

30. Mehra R, Bala P. Effect of ventilation conditions on the annual effective dose due to indoor radon concentration. Advances in Applied Science Research. 2013;4(1):212-215.

31. Traore I, Nachab A, BA A, Nourreddine A, Togo V. Assessment of activity and effective dose rate of $222 \mathrm{Rn}$ in several dwellings in Bamako, Mali. Radioprotection. 2013;48(2):277-284. https://doi.org/10.1051/radiopro/2012050

32. Szacsvai K, Cosma C, Cucos A. Indoor radon exposure in Cluj-Napoca city Romania. Rom Journ Phys. 2013;58:S273-S279.

33. UNSCEAR, United Nation Scientific Committee on the Effects of Atomic Radiation. Sources and Effects of Ionizing Radiation, United Nations: New York (1993).

34. Celik N, Cevik U, Kucukomeroglu B. Determination of indoor radon and soil radioactivity levels in Giresun, Turkey. Journal of Environmental Radioactivity. 2008;99(9):1349-1354. https://doi.org/10.1016/j.jenvrad.2008.04.010

35. Elzain AEA, Sam AK, Mukhtar OM, Abbasher MA. A Survey of Indoor Radon-222 levels in Kassala town. Gezira j of eng \& applied sci. 2008;3(2):72-100.

36. Al-saadi AJ. Determination of Radon Concentration and the Annual Effective Dose in Karbala University Campus, Karbala, Iraq. Karbala J Med. 2013;6(1): 1591-1599.

37. Amin RF. Evaluation of radon gas concentration in the drinking water and dwellings of south-west Libya, using CR-39 detectors. International Journal of Environmental Sciences. 2013;4(4):484-490.

38. EPA (U.S. Environmental Protection Agency). National Residential Radon Survey. Vol. 1: national and regional estimates, Report prepared for the Office of Radiation Programs. 1999

39. Papaefthymiou H, Mavroudis A, Kritidis P. Indoor radon levels and influencing factors in houses of Patras, Greece Journal of Environmental Radioactivity. 2003;66(3):247-260. https://doi.org/10.1016/S0265-931X(02)00110-8

40. Al-Saleh FS. Measurements of indoor gamma radiation and radon concentrations in dwellings of Riyadh City, Saudi Arabia. Applied Radiation and Isotopes. 2007;65(7):843-848. https://doi.org/10.1016/j.apradiso.2007.01.021

41. Khayrat AH, Al-Jarallah MI, Fazal-ur-Rehman X, Abu-Jarad F. Indoor radon survey in dwellings of some regions in Yemen. Radiat Meas. 2003;36:449-451. https://doi.org/10.1016/S1350-4487(03)00169-0 